УДК 631.87/ 634.8.076/ 663.253.34/ 579.64

(C) 2018

Кована О. О., молодший науковий співробітник хіміко-аналітичної лабораторії відділу виноробства,

Тарасова В. В., молодший науковий співробітник хіміко-аналітичної лабораторії відділу виноробства,

Мулюкіна Н. А., доктор сільскогосподарських наук

Національний науковий центр «Інститут виноградарства і виноробства ім. В. С. Таїрова»

\title{
ВПЛИВ ЕМ-ПРЕПАРАТІВ НА АГРОБІОЛОГІЧНІ ТА ТЕХНОЛОГІЧНІ ПОКАЗНИКИ СОРТІВ ВИНОГРАДУ СЕЛЕКЦІЇ ННЦ «ІВіВ ім. В. Є. ТАЇРОВА»
}

\author{
Рецензент - Л. В. Герус, старший науковий співробітник відділу селекції, генетики та \\ ампелографії Національного наукового центру «Інститут виноградарства і виноробства \\ ім. В. . Таӥрова»
}

Оцінено вплив препарату «ЕМ-агро» на показники продуктивності, а саме підвищення врожайності до $37 \%$, в основному, за рахунок збільшення маси ягід. Інокуляція мікроорганізмів до екосистеми та їх включення до мікробних угруповань листкової поверхні винограду сприяла вилученню фенольних та барвних речовин, зниженню активності о-дифенолоксидази у дослідних зразків та запобіганню окислення фенольних речовин. Отримані результати дозволяють рекомендувати застосування ЕМ-препаратів для органічного виноградарства та виноробства як з точки зору підвищення продуктивності винограду, так $i$ з огляду на покращення технологічних показників.

Ключові слова: виноград, ЕM-препарат, виноматеріали, органічне виноградарство, Агат таїровський, Чарівний, Одеський жемчуг.

Постановка проблеми. Органічне виноградарство сьогодні є одним з основних трендів у галузі виноградарства і виноробства. За даними Швейцарського інституту органічного землеробства (FiBL), на 2014 рік у світі вже налічувалося майже 316 тис. га органічних виноградників, що становить приблизно 4,5 \% від загальної площі виноградників в світі [7]. У порівнянні з 2004 роком, площі під органічними виноградниками виросли більш ніж в три рази, особливо в провідних виноградарських країнах - Іспанії, Франції, Італії, Китаї та Туреччині. Сьогодні в Свропі за принципами органічного сільського господарства оброблюються 266 тис. га виноградників, це більше ніж 90\% органічних виноградників усього світу. В Україні площа зареєстрованих органічних виноградників в 2014 році становила 140 га (це 0,2\% від площі всіх виноградників), проте ці площі постійно збільшуються.

Аналіз основних досліджень і публікацій, у яких започатковано розв'язання проблеми. Основною вимогою системи удобрення в органічному виноградарстві $є$ збереження природної родючості і біологічної активності грунту або iï підвищення, а всі препарати, дозволені до використання захисту рослин, мають природне походження і контактний механізм дії [7].

Така вимога пояснюється негативним впливом ряду пестицидів на якість винограду і вина. Так, при переробці винограду визначено, що з підвищенням кількості залишку бензимідазолів (ОКБ) у виноградному суслі активність бродіння сповільнюється, особливо при бродінні сусла 3 червоного сорту винограду, та підвищується ймовірність виникнення зупинки бродіння [10]. Fatihenti та його колеги відзначають, що після ферментації Saccharomyces cerevisiae, дельтаметрін, перметрин та фенвалерат повністю деградуються, що можна пояснити дією дріжджів, тоді як фунгіциди беналалксил, фольпе, фуралаксил, металаксил іпродіон, просимідон залишалися незмінними (Fatihenti et al., 1983 i 1984) [10, 11]. У готовій продукції знайдено такі речовини як боскалід та фенгексамід, ципродініл і диметоморф, флудиоксоні, металаксил і просимідон, азоксистробін та іпродіон [8].

У результаті аналізу комерційних червоних, білих та рожевих вин було знайдено залишки фунгіцидів та визначено, що забруднення пестицидами $є$ проблемою в усьому світі з можливими наслідками для здоров'я споживачів та міжнародної торгівлі [9].

Виходячи 3 основних вимог до ведення органічного виноградарства, які стосуються удобрення та захисту виноградників, в якості препаратів для захисту насаджень від основних грибних хвороб при органічному способі ведення культури доцільним $€$ використання ефективних мікроорганізмів. Дану концепцію розробив професор Теруо Хіга, Університет Рюкюса, Окінава, Японія. Використання суміші препаратів ЕМ-А та ЕМ-5 істотно прискорює мінералізацію грунту 


\section{СІЛЬСЬКЕ ГОСПОДАРСТВО. РОСЛИННИЦТВО}

та сприяє зниженню кислотності грунту [13].

Позитивні результати отримані на однорічних культурах (зерняткові, овочеві та ін.). Так, ЕМ, що застосовується в комбінації з хімічними добривами, значно збільшують урожайність та поживні властивості рису та пшениці в порівнянні 3 цими методами, що застосовуються окремо [14]. За даними досліджень І. Івазе, протягом трьох років використання пестицидів зменшилось на 70\% у результаті заміни ї на ЕMпрепарати. Впровадження корисних мікроорганізмів для посилення росту та врожайності таких культур як капуста та редька сприяли щільності капустяних голів та м'якості коренеплодів редьки, які зберігаються більш тривалий період [16]. Застосування ЕМ-препаратів позитивно вплинуло на ріст кореневої системи та надземних частин яблуневої підщепи [17].

За даними італійських дослідників, позитивний вплив ЕМ виявлений також на винограді [15].

Окрім підвищення родючості грунту, покращення якості та кількості врожаю інокульовані мікроорганізми в певній мірі можуть підвищити толерантність рослин до стресових абіотичних факторів, таких як посуха, підвищений вміст солей у грунті, токсичність металу та висока температура. Як повідомляється у літературних джерелах останніх десятиліть, бактерії, які належать до різних родів, включаючи бактерії Rhizobium, Bacillus, Pseudomonas, Pantoea, Paenibacillus, Burkholderia, Achromobacter, Azospirillum, Microbacterium, Methylobacterium, variovorax, Enterobacter та ін., забезпечують толерантність рослин-господарів до різних абіотичних стресових факторів [12].

Таким чином, аналіз даних наукових досліджень вчених виноградарських країн світу підтверджує, що підвищення якості продукції сільськогосподарських культур, збереження врожаю на всіх етапах біологічного циклу рослини можливе не тільки шляхом використання хімічних добрив та пестицидів, а й за рахунок інокуляції мікроорганізмів до ареалу вирощування даної культури. В Україні ЕМ-препарати застосовували на зернових культурах, таких як ячмінь $[5,6]$ та пшениця [4]. На багаторічних рослинах, зокрема у виноградарстві, їх застосування було досліджено лише у виноградному розсадництві [1].

Мета досліджень: вивчення впливу препарату «ЕМ-агро» на показники продуктивності та механічного складу ягід перспективних форм селекції ННЦ «ІВіB ім. В. Є. Таїрова» (Одеський жемчуг, Чарівний, Агат таїровський) та на вміст фенольних речовин і здатності до їх віддачі під час технологічних операцій.

Завдання досліджень:

- дослідити вплив препарату «ЕМ-агро» на показники продуктивності (кількість грон на кущі та їх масу, урожайність 3 куща та одного гектару) та на механічний склад грона (маса ягід, маса гребенів, маса насіння, маса шкірки, маса сусла і щільних частин м'якоті, кількість насінин у 100 ягодах) червоних технічних форм Одеський жемчуг, Чарівний, Агат таїровський;

- вивчити вплив препарату «ЕМ-агро» на показники фенольного комплексу винограду та його стійкість до окислення;

- оцінити перспективність використання ЕМпрепаратів у виноградарстві та виноробстві.

Матеріали і методи досліджень. Дослідження проводилися у 2017 р. на виноградниках ННЦ « IBiB ім. В. С. Таїрова», розташованого у пгт. Таїрове Овідіопільського району Одеської області, 46²1ПнШ 30³9'31 СД. Тип грунтів - південні чорноземи, без зрошення. Схема формування - двобічний горизонтальний кордон на штамбі заввишки 80 см.

Матеріалом дослідження $є$ :

- виноград раннього терміну достигання селекції ННЦ «ІВіВ ім. В. Є. Таїрова»-Одеський жемчуг, Чарівний, Агат таїровський. Масова концентрація цукрів у суслі всіх зразків селекційних форм винограду коливалась в діапазоні 180-226 г/дм³ . Масова концентрація титрованих кислот мала найвище значення 7,8 г/дм ${ }^{3}$ для форми винограду Одеський жемчуг, а найменше - для винограду форми Чарівний (7,2 г/дм³).

- ЕМ-препарати, які містять вибрані види мікроорганізмів, де переважають популяції молочнокислих бактерій i дріжджів, а також менша кількість фотосинтезуючих бактерій, актиноміцетів та інших типів мікроорганізмів. Всі вони взаємно сумісні один з одним і можуть співіснувати в рідкій культурі.

Методи досліджень: впродовж вегетації проводили обприскування поверхні виноградної рослини (листя та грона) один раз на два тижні розчином «ЕМ-агро». Для роботи використовували розведення 1:500. В якості контролю використовували обприскування винограду водою без ЕМ. На рисунку 1 зображено етапи (цвітіння винограду, ріст ягід та достигання ягід) обробки винограду форми Агат таїровський у період вегетації.

Агробіологічні показники та механічний склад грона визначали за методичними рекомендаціями М. А. Лазаревського (1963 р.). 


\section{1. Технологічна характеристика винограду}

\begin{tabular}{|c|c|c|c|}
\hline Сорт/форма винограду & $\begin{array}{c}\text { Масова концентрація } \\
\text { цукрів, г/дм }\end{array}$ & $\begin{array}{c}\text { Масова концентрація титрова- } \\
\text { них кислот, г/дм }{ }^{3}\end{array}$ & $\mathrm{pH}$ \\
\hline Агат таїровський & 226 & 7,5 & 3,3 \\
\hline Одеський жемчуг & 186 & 7,8 & 3,8 \\
\hline Чарівний & 180 & 7,2 & 3,4 \\
\hline
\end{tabular}

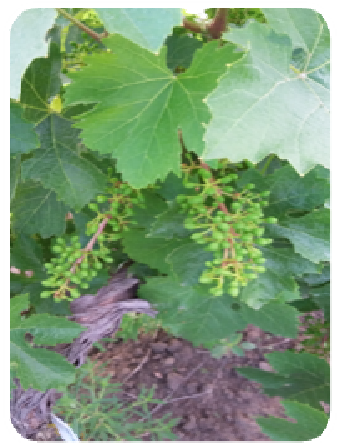

Цвітіння винограду

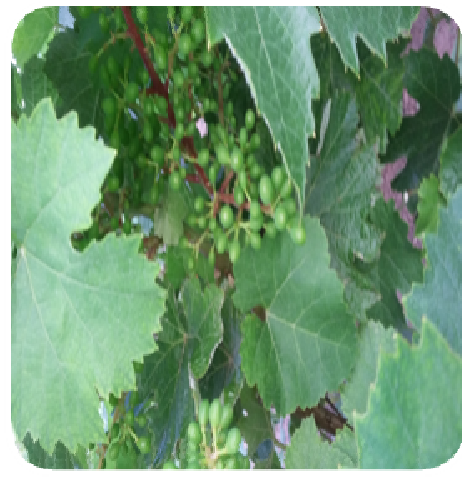

Ріст ягід
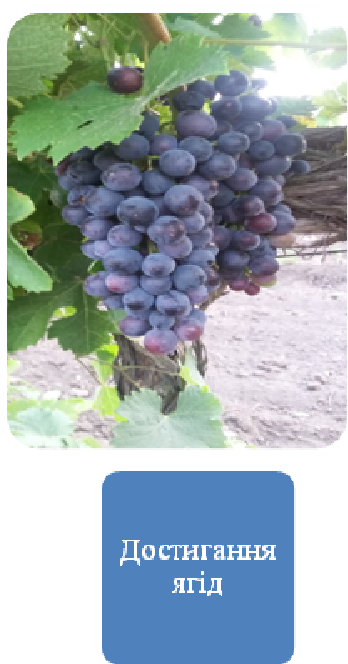

Рис 1. Фенологічні фази форми Агат тайровський на момент обробок куща препаратом «ЕМ-агро»

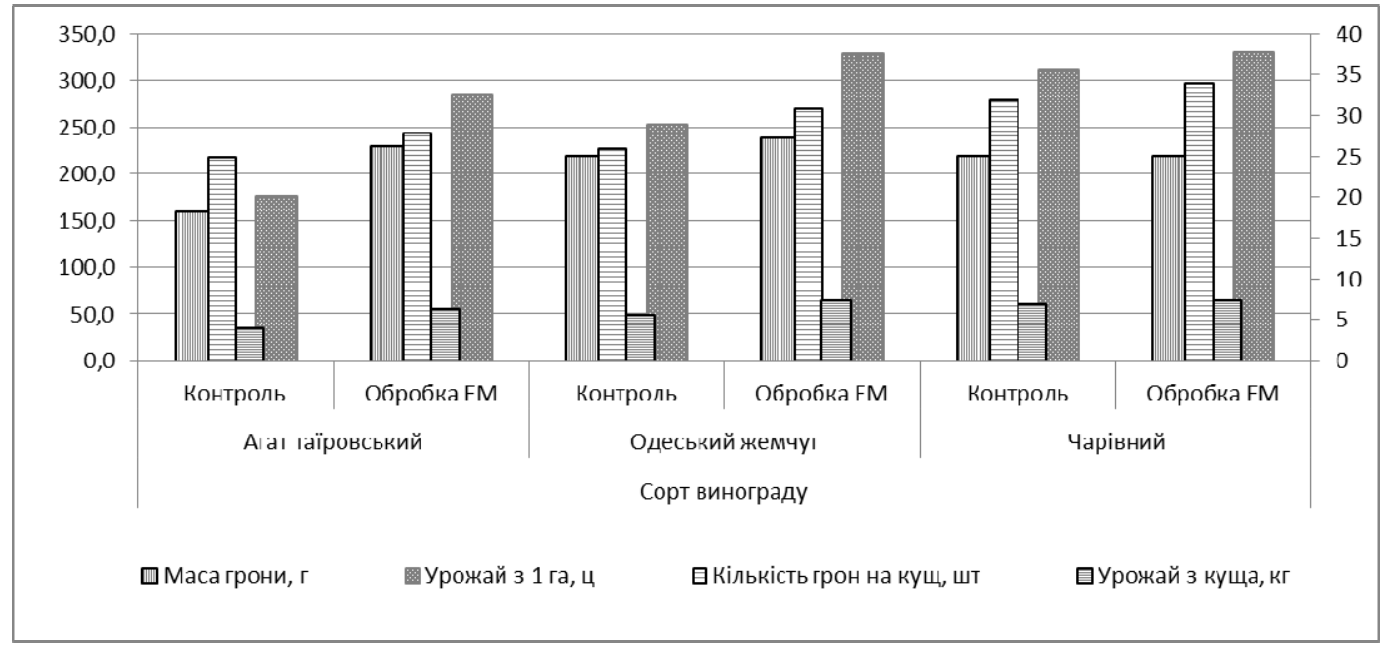

Рис 2. Вплив "ЕМ-агро» на продуктивність технічних форм винограду селекції ННЦ «ІВіВ ім. В. С. Таїрова»

Технологічний запас фенольних та барвних речовин визначали колориметричними методами. Визначення активності о-дифенолоксидази проводили за допомогою фотоелектроколориметра, вимірюючи активність ферменту за швидкістю утворення синьо-фіолетового забарвлення окисленого сірчанокислого диетилпарафенілдіаміну [2].

Результати досліджень. Урожайність є одним 3 головних показників продуктивності виногра- ду. У результаті проведених досліджень встановлено, що урожайність досліджуваних форм $€$ досить високою та коливається від 177,8 (Агат таїровський) до 312,9 ц/га (Чарівний).

При застосуванні обробки винограду ЕМпрепаратами спостерігається підвищення врожайності порівняно із контролем, що пояснюється збільшенням маси грона від $9 \%$ (Одеський жемчуг) до 30\% (Агат таїровський).

Механічний склад грона винограду є сорто- 
вою особливістю і коливається в широких межах. Співвідношення складових елементів грона (гребеня та ягід і їх компонентів) досліджують для визначення потенціалу нових сортів винограду та направлення їх у переробці.

Встановлено, що досліджувані форми винограду Одеський жемчуг, Чарівний, Агат таїровський відрізняються за масою складових частин грона і ягід; маса грона коливається у контрольних зразках в межах 160-220 г, а маса ягід - у межах 153-212 г.

Обробка насаджень ефективними мікроорганізмами позитивно впливає на співвідношення складових частин грона винограду та його масу. Приріст маси грона спостерігався до 40 \%, в основному, за рахунок збільшення маси ягід. 3 таблиці 2 видно, що маса ягід для форми винограду Чарівний залишається без змін, а для двох інших досліджуваних зразків цей показник збільшується до $30 \%$ (Агат таїровський).

Технологічний запас фенольних та барвних речовин $є$ одним 3 основних показників при переробці винограду за «червоним способом». Для оцінки здатності винограду до віддачі даних речовин проводили нагрів м'язги до $70^{\circ}$ та витримку при цій температурі 1 годину. Встановлено, що у результаті нагрівання вміст фенольних речовин збільшується від $5 \%$ (для винограду форми Чарівний) до $106 \%$ (форма Одеський жемчуг). Масова концентрація фенольних речовин (ТЗ ФР) у досліджуваних форм винограду коливалась від 742,7 до 1202,0 мг/дм ${ }^{3}$. Найвище значення відповідає формі Одеський жемчуг. Технологічний запас барвних речовин складає, у середньому, 40 \% від ТЗ ФР.

Результати дослідження впливу препарату «ЕМ-агро» на показники фенольного комплексу винограду наведені на рисунку 3. Визначено, що обробка винограду препаратом «ЕМ-агро» позитивно впливає на вилучення фенольних та барвних речовин для усіх досліджених форм. Так, ТЗ ФР для винограду Агат таїровський збільшується лише на $2 \%$, тоді як для винограду форм Чарівний та Одеський жемчуг - в середньому на $35 \%$. Аналогічно змінюється і масова концентрація барвних речовин. Крім цього, форма Одеський жемчуг характеризується кращою віддачею барвних речовин при нагріванні по відношенню до фенольних речовин в досліджуваному зразку.

\section{2. Вилив препарату «ЕМ-агро» на механічний склад виноградного грона (ННЦ «ІВіВ ім. В. С. Таӥрова», 2017 р.)}

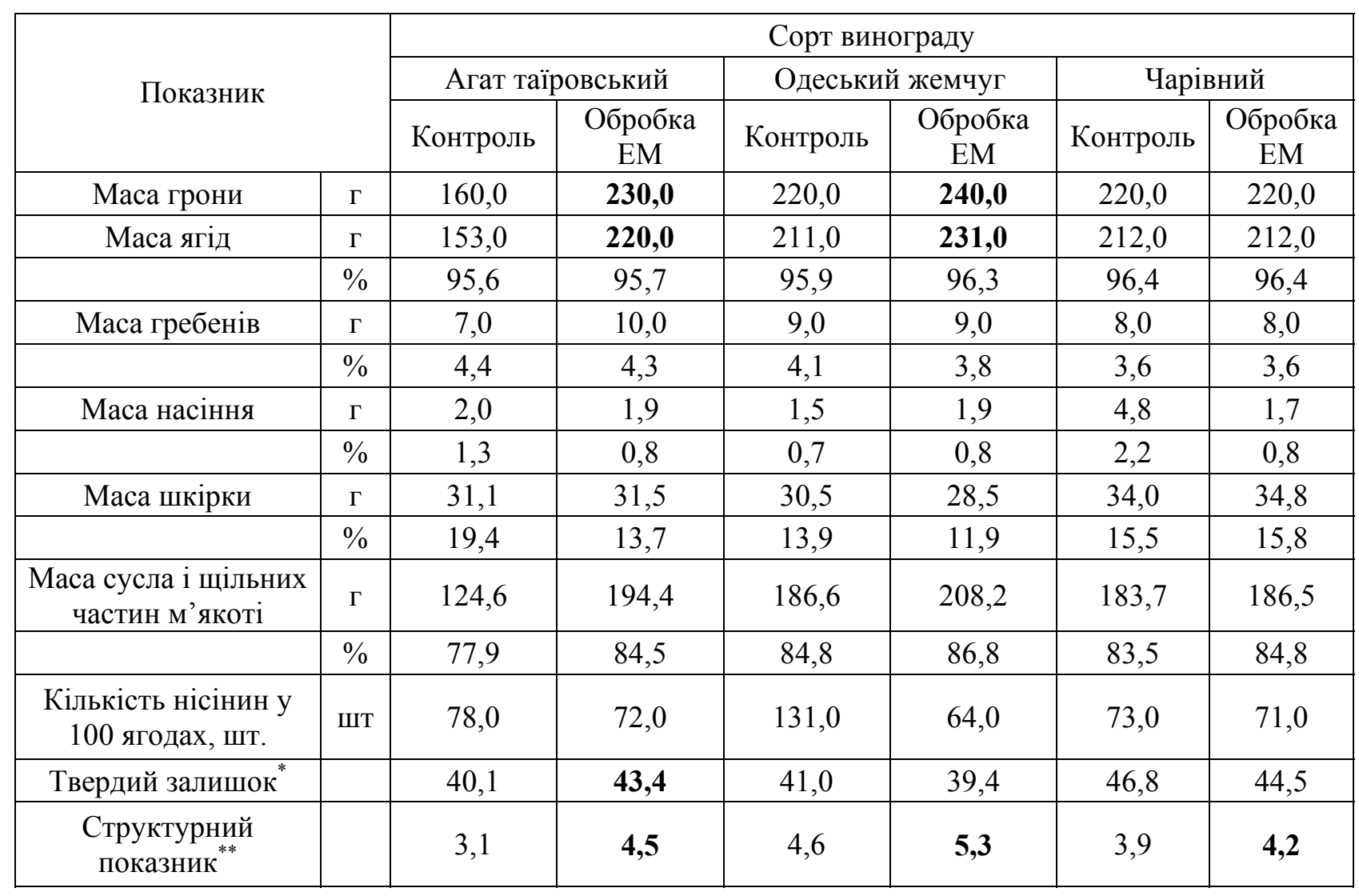

Примітка: * Твердий залишок - сума гребенів, шкірочки та насіння;

$$
\text { ** Структурний показник - відношення м'якоті до твердого залишку. }
$$




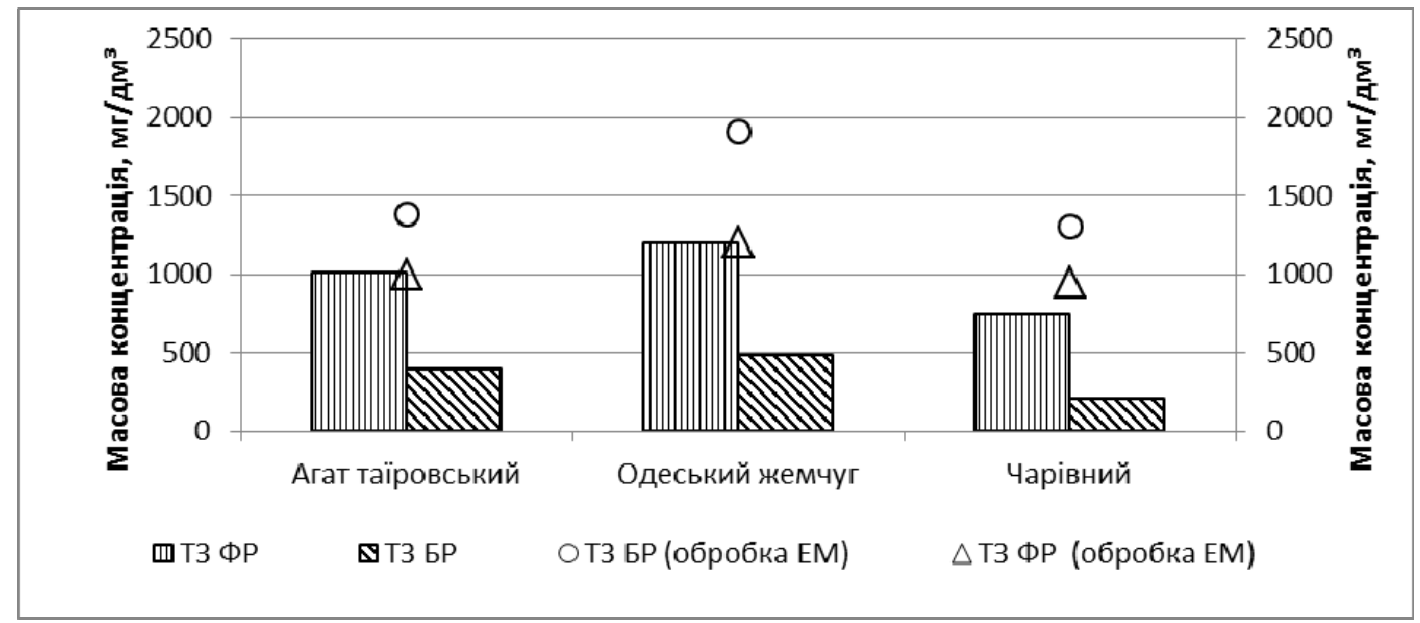

Рис. 3. Вплив препарату «ЕМ-агро» на показники фенольного комплексу винограду

Примітка: ТЗ ФР - технологічний запас фенольних речовин; ТЗ БР - технологічний запас барвних речовин.

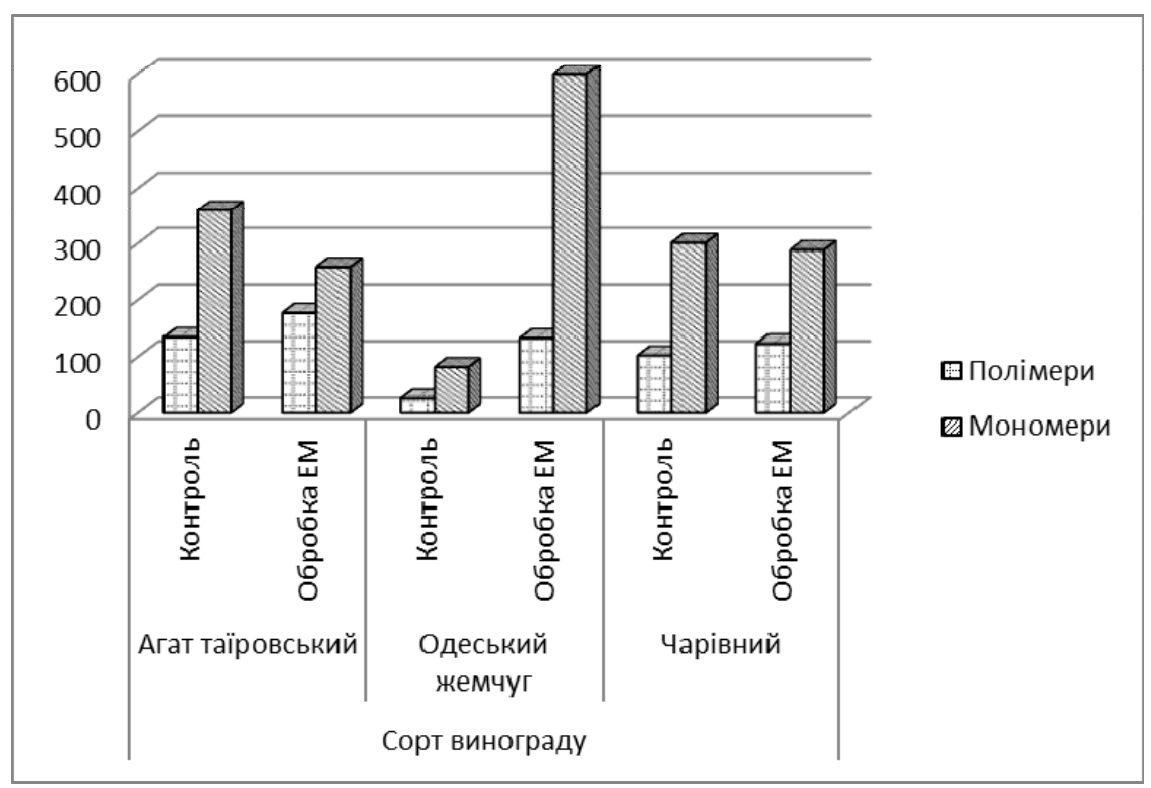

Рисунок 4. Вплив препарату «ЕМ-агро» на співвідношення полімерних та мономерних форм фенольних речовин винограду

Роглянемо вплив препарату «ЕМ-агро» на технологічні показники червоних технічних форм винограду селекції ННЦ « $\mathrm{IBiB}$ ім. В. С. Таїрова». Відомо, що полімерні форми фенольних речовин сприяють зниженню в'яжучих та гірких смакових властивостей вин та забезпечують повноту смаку вин. На рисунку 4 відображено співвідношення полімерних та мономерних форм фенольних речовин. У контрольних зразках винограду переважають саме мономерні форми, та складають 73-96 \% загального вмісту фенольних речовин. У результаті обробки винограду цей показник зменшується на 5-15\% у сторону полімерних форм.

Хімічне та ферментне окислення фенольних сполук призводить до утворення високоефективних проміжних сполук (хінонів), які взаємодіють $з$ амінокислотами, призводячи до зменшення вмісту цукру та алкоголю, при цьому утворюються леткі речовини. У результаті вина втрачають свіжість, спостерігається пожовтіння та буріння вина, втрата прозорості та блиску.

Окислення фенольних речовин відбувається під дією ферменту о-дифелоксидази та перексидази. В результаті досліджень було виявлено зниження активності о-дифенолксидази у зразках вина 3 усіх 3-х форм винограду, обробленого препаратом «ЕМ-агро». Як видно з рисунку 5, завдяки цьому окислення цих речовин протікає менш інтенсивно. 


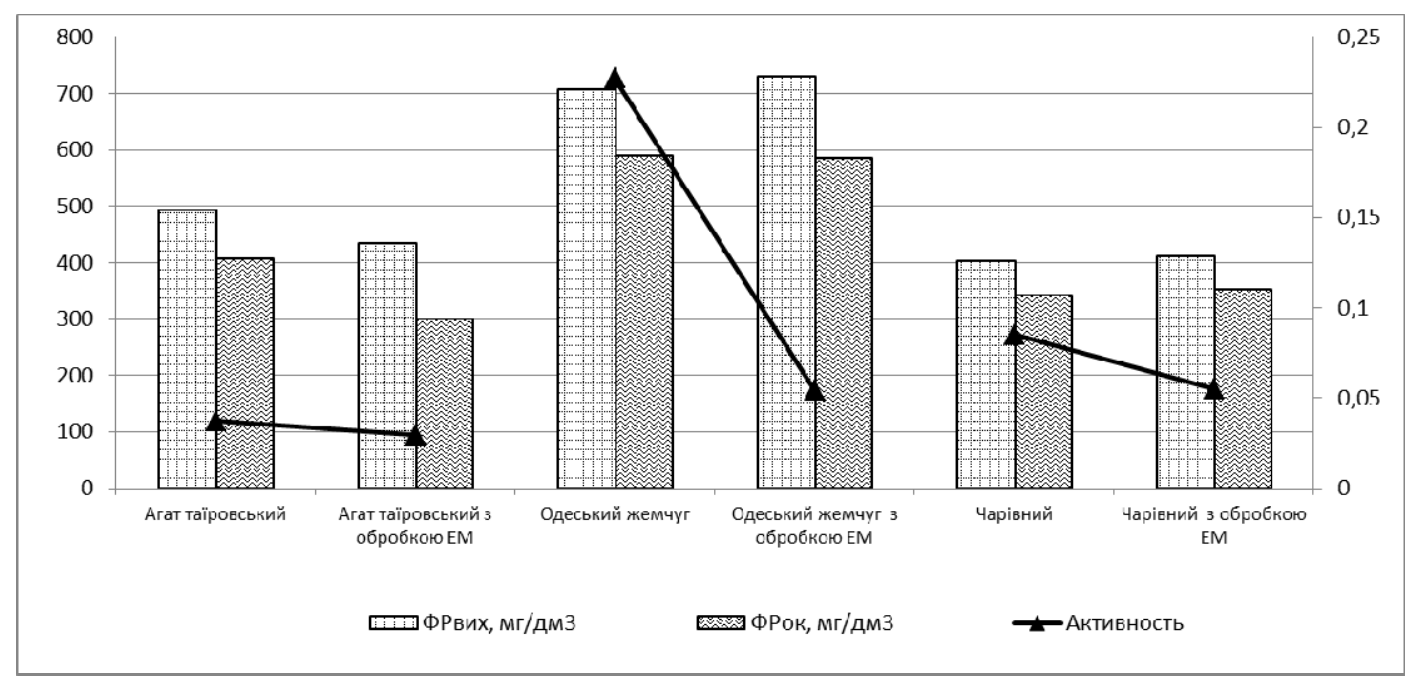

Рис. 5. Виливу препарату «ЕМ-агро» на збереження фенольних речовин від окислення за рахунок зниження активності ферменту о-дифенолоксидази.

\section{Висновки}

1. У результаті проведеної обробки дослідних форм винограду ЕМ-препаратами спостерігається покращення агробіологічних показників, зокрема, підвищення врожайності на 6-37\%, це пояснюється збільшенням маси грона до $40 \%$, в основному за рахунок збільшення маси ягід.

2. Визначено, що обробка всіх дослідних форм винограду позитивно впливає на вилучення фенольних та барвних речовин (максимально збільшуючи їх до $35 \%$ у форм Чарівний та

\section{БІБЛІОГРАФІЯ}

1. Зеленянська Н. М., Бах Н. К. Удосконалення технологічних прийомів виробництва садивного матеріалу винограду на основі застосування ЕМ-препаратів // Аграрний вісник Причорномор'я. Сільськогосподарські науки. 2015. № 76. С.40-45. Лазаревский М.А. Изучение сортов винограда / М.А. Лазаревский. - Ростовна-Дону: Издательство Ростовского унив-та, 1963. - С. 152.

2. Методические указания. Методика оценки сортов по физико-химическим биохимическим показателям: РД3483.042-2005- [Действ. 200512-02]. - Ялта, ИВиВ «Магарач». - 2005. - 22 с.

3. Разработка методики анализа остаточных концентраций фунгицидов бензимидазольной природы методом высокоэффективного капиллярного электрофореза / Н.М. Агеева та ін. // III Международной научно-практической конференции, посвященной 20-летнему юбилею ГНУ КНИИХП Россельхозакадемии. - Краснодар: ООО «Издательский Дом Юг», 2013. - С. 251253.
Одеський жемчуг). Зміщується співвідношення мономерів до полімерів у бік останніх. Одночасно 3 цим обробка препаратом «ЕМагро» знижує активність о-дифенолоксидази у дослідних зразків, тим самим зберігаючи фенольні речовини від окислення.

3. Застосування ЕМ-препаратів може бути рекомендоване для органічного виноградарства та виноробства як 3 точки зору підвищення продуктивності винограду, так і 3 огляду на покращення технологічних показників.

4. Рожков А. О. Варіабельність урожайності рослин пшениці твердої ярої за дії різних способів сівби, норм висіву та позакореневих підживлень біопрепаратами // Наукові праці Південного філіалу Національного університету біоресурсів і природокористування України Кримський агротехнологічний університет. Серія: Сільськогосподарські науки. - 2013. № 154. - C. 48-54.

5. Рожков А. О. Урожайність ячменю ярого сорту Докучаєвський 15 залежно від застосування різних норм висіву та позакореневих підживлень / А. О. Рожков, С. В. Чернобай // Вісник Полтавської державної аграрної академії. - 2014. - № 4. - С. 30-34.

6. Чернобай С. В. Формування показників якості зерна ячменю ярого за впливу норми висіву та позакореневих підживлень / С. В. Чернобай // Вісник аграрної науки Причорномор'я. 2014. - Вип. 4 (81). - С. 163.

7. Штірбу А. В. Органічне виноградарство: стан, проблеми, перспективи [Текст] / В. В. Власов, Н. А. Мулюкіна, А. В. Штирбу та ін. // 
Наукові основи виробництва органічної продукції в Україні монографія / за ред. Я. М. Гадзала, В. Ф. Калінського - К. : Аграрна наука, 2016. - С. 254-258.

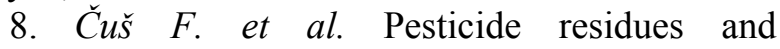
microbiological quality of bottled wines // Food Control. - 2010. - T. 21. - №. 2. - C. 150-154.

9. Esteve-Turrillas $F$. A. et al. Fungicide multiresidue monitoring in international wines by immunoassays //Food chemistry. - 2016. - T. 196. C. 1279-1286.

10. Fatichenti, F., Farris, G. A., Deiana, P., Cabras, P., Meloni, M., and Pirisi, F. M. (1984). The effect of Saccharomyces cerevisiae on concentration of dicarboximide and acylamide. fungicides and pyrethroid insecticides during fermentation. Appl. Microbiol. Biotech. 20:419421.

11. Fatichenti, F., Farris, G. A., Deiana, P., Cabras, P., Meloni, M., and Pirisi, F. M. (1983). Apreliminary investigation into the effect of Saccharomyces cerevisiae on pesticide concentration during fermentation. Eur. J. Appl. Microbiol. Biotech. 18:323-325.

12. Grover $M$. et al. Role of microorganisms in adaptation of agriculture crops to abiotic stresses //
World Journal of Microbiology and Biotechnology. - 2011. - T. 27. - №. 5. - C. 1231-1240.

13. Higa T., Parr J. F. Beneficial and effective microorganisms for a sustainable agriculture and environment. - Atami, Japan : International Nature Farming Research Center, 1994. - T. 1.

14. Hussain T. et al. Rice and wheat production in Pakistan with effective microorganisms //American Journal of Alternative Agriculture. 1999. - T. 14. - №. 1. - C. 30-36.

15. Vercesi $A$. Experimental research into the influence of treatments with preparations based on bacteria mixtures (EM Bio-nrg srl) upon the nutritional condition and health of vines (20072009).

16. Yadav S. P. Performance of effective microorganisms (EM) on growth and yields of selected vegetables //Nature Farming \& Environment. 2002. - T. 1. - C. 35-38.

17. Zydlik P., Zydlik Z., 2008. Impact of biological effective microorganisms (EM) preparations on some physico-chemical properties of soil and the vegetative growth of apple-tree rootstocks. Nauka Przyr. Technol. 2, 1, \#4. 